\title{
Resistance of New Strawberry Genotypes to the Two-Spotted Spider Mite (Acari: Tetranychidae)
}

\author{
Fernanda de Cássia Neves Esteca ${ }^{1}$, Camila do Nascimento Dainese ${ }^{1}$, Luis Rodolfo Rodrigues ${ }^{1}$, \\ André Luiz Lourenção ${ }^{2}$, Francisco Antonio Passos ${ }^{2} \&$ Gilberto José de Moraes ${ }^{1}$ \\ ${ }^{1}$ Departamento de Entomologia e Acarologia, Escola Superior de Agricultura "Luiz de Queiroz”, Universidade \\ de São Paulo, Piracicaba, SP, Brazil \\ ${ }^{2}$ Instituto Agronômico de Campinas (IAC), Campinas, Brazil \\ Correspondence: Fernanda de Cássia Neves Esteca, Departamento de Entomologia e Acarologia, Escola \\ Superior de Agricultura "Luiz de Queiroz", Universidade de São Paulo, Av. Pádua Dias, 11, 13418-900, \\ Piracicaba, SP, Brazil. E-mail: fernanda.esteca@usp.br
}

Received: April 27, $2017 \quad$ Accepted: May 31, $2017 \quad$ Online Published: July 15, 2017

doi:10.5539/jas.v9n8p119 URL: https://doi.org/10.5539/jas.v9n8p119

This study was funded by CAPES (Coordenação de Aperfeiçoamento de Pessoal de Nivel Superior).

\begin{abstract}
The two-spotted spider mite, Tetranychus urticae Koch, is one of the main strawberry pests in Brazil and many other countries. The objective of this study was to compare the resistance of eight strawberry genotypes ('Albion', 'IAC Guarani', 'IAC Princesa Isabel', 'Oso Grande', IAC T-0104, IAC 12, IAC 4 and IAC 1.13) to the two-spotted spider mite, by assessing injury level, biological parameters and host preference of the mite. To facilitate the interpretation of the results, leaf trichomes of each genotype were quantified. Thirty days after the artificial infestation of the genotypes with the mite, IAC T-0104, IAC 12 and 'IAC Princesa Isabel' showed the lowest injury levels. 'IAC Princesa Isabel', IAC 4 and IAC T-0104 were distinguished from other genotypes by the highest mean generation time (T) of the mite, while 'IAC Guarani' was distinguished by the lowest $\mathrm{T}$ value. Significantly lower values of intrinsic rate of increase $\left(\mathrm{r}_{\mathrm{m}}\right)$, finite rate of increase $(\lambda)$ and net reproductive rate $\left(\mathrm{R}_{\mathrm{o}}\right)$ were determined on 'IAC Princesa Isabel' and IAC 1.13. The mite showed preference for 'IAC Guarani', as inferred by the larger number of females when offered the chance to select the detached host leaflets. Trichome density was highest on IAC 1.13 and lowest on IAC T-0104, IAC 12, 'Albion' and 'Oso Grande'. The results suggested that 'IAC Princesa Isabel', IAC T-0104 and IAC 12 are resistant, IAC 4 and IAC 1.13 are moderately resistant, and 'IAC Guarani', 'Oso Grande' and 'Albion' are susceptible to the mite.
\end{abstract}

Keywords: Fragaria $\times$ ananassa Duch., host plant resistance, two-spotted spider mite

\section{Introduction}

Strawberry (Fragaria $\times$ ananassa Duch.) (Rosaceae) is the main horticultural fruit crop produced in Brazil (Fachinello, Pasa, Schmtiz, \& Betemps, 2011). The two-spotted spider mite, Tetranychus urticae Koch, is considered one of the main strawberry pests in that country and many others (Klingen \& Westrum, 2007; Moraes \& Flechtmann, 2008; Dias, Filho, Carmo, \& Simões, 2012). Attacked leaves are initially discolored and may later dry and become totally covered with webbing, leading to up to $80 \%$ yield reduction and lower fruit quality (Park \& Lee, 2005; Fraulo, Mcsorley, \& Liburd, 2008).

Control of this pest is mainly done with the application of synthetic acaricides (Van Leeuwen, Vontas, Tsagkarakou, Dermauw, \& Tirry, 2010; Attia et al., 2013; León, Guzmán, García, Chávez, \& Penã, 2014). However, the excessive use of these products can lead to resistance development, that in turn results in more intensive use of the same or other products and, in parallel, the elimination of populations of beneficial arthropods, secondary pest outbreaks and higher levels of toxic residues on fruits (Cavalcanti et al., 2010).

Alternative control tactics involve mainly biological control (McMurtry \& Croft, 1997; Oliveira et al., 2007; McMurtry, Moraes, \& Sourassou, 2013), but the use of resistant cultivars has also been considered (González-Domínguez, Santillán-Galicia, González-Hernández, Espinosa, \& González-Hernández, 2015). Several studies have shown significant differences between strawberry genotypes in relation to susceptibility to 
the two-spotted spider mite (Lourenção, Moraes, Passos, Ambrosano, \& Silva, 2000; El-Shafei \& Gotoh, 2010; Afifi, El-Laithy, Shehata, \& El-Saiedy, 2010; Monteiro, Kuhn, Mogor, \& Silva, 2014; González-Domínguez et al., 2015). Varietal resistance can be evaluated through the evaluation of factors such as mite behavior, level of inflicted plant injury (Petrova, Cudare, Steinite, \& Laugale, 2000; Wold \& Hutchison, 2003), developmental time, survivorship, fecundity, oviposition rate and life table parameters (Gugole Ottaviano, Sánchez, Roggiero, \& Greco, 2013; González-Domínguez et al., 2015). Factors related to resistance to mite pests include morphological characteristics such as tissue thickness and density of trichomes (Handley, Ekbom, \& Agren, 2005; Oku, Yano, \& Takafuji, 2006; González-Domínguez et al., 2015), as well as the production of defense compounds, which often inhibit mite feeding (Steinite \& Ievinsh, 2002; Figueiredo, Resende, Morales, Gonçalves, \& Da Silva, 2013). The aim of this study was to compare the resistance of eight strawberry genotypes to the two-spotted spider mite, by assessing injury level, biological parameters and host preference.

\section{Materials and Methods}

\subsection{Sources of Plants and Mites}

The genotypes used in the study were obtained from the strawberry Active Germplasm Bank of Instituto Agronômico de Campinas (IAC) (Table 1), including four commercial cultivars ('Albion', 'IAC Guarani', 'IAC Princesa Isabel' and 'Oso Grande') and four genotypes under development by the IAC Breeding program for resistance to the spider mite (IAC T-0104, IAC 12, IAC 4 and IAC 1.13). 'Albion' and 'Oso Grande' are commonly used by growers of southeastern Brazil. 'IAC Guarani' and 'IAC Princesa Isabel' are cultivars not used commercially anymore, but they were used respectively as susceptible and resistant controls (Lourenção et al., 2000).

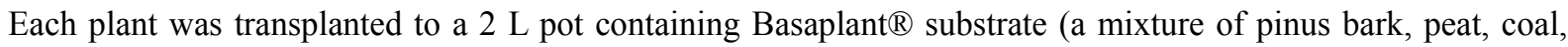
vermiculite, initial fertilization with NPK and micronutrients). Plants were fertilized bi-weekly, alternating the use of two types of fertilizers, granulated 12-06-12 and soluble 15-15-20.

The specimens of two-spotted spider mite used in this study were obtained from a colony initiated with mites collected from bean plants (Phaseolus vulgaris L.) in Piracicaba, São Paulo State, Brazil.

Table 1. Details about the strawberry genotypes evaluated in the present study

\begin{tabular}{|c|c|c|}
\hline Genotype & Pedigree/Origin & Characteristics \\
\hline 'Albion’ & $\begin{array}{l}\text { ('Diamante' } \times \text { Cal. 94.16-1)/University of California, } \\
\text { USA; cultivar launched in } 2006\end{array}$ & $\begin{array}{l}\text { For fresh consumption, productive, firm fruits, with } \\
\text { individual peduncles and neutral to photoperiod }\end{array}$ \\
\hline 'IAC Guarani' & $\begin{array}{l}\text { [('IAC Campinas' } \times \text { 'IAC Monte Alegre') } \times \\
\text { 'Alemanha']/IAC; cultivar launched in } 1979\end{array}$ & $\begin{array}{l}\text { For industry, precocious, productive, medium fruit, } \\
\text { firm, intense external and internal red color and in } \\
\text { bunch. }\end{array}$ \\
\hline 'IAC Princesa Isabel' & $\begin{array}{l}\text { ('Alemanha' } \times \text { 'IAC Jundiaí')/IAC; } \\
\text { cultivar launched in } 1989\end{array}$ & $\begin{array}{l}\text { For fresh consumption, precocious, productive, great } \\
\text { fruit, firm and in bunch. }\end{array}$ \\
\hline 'Oso Grande' & $\begin{array}{l}\text { ('Parker' } \times \text { CA77.3-603)/University of California, USA; } \\
\text { cultivar launched in } 1987\end{array}$ & $\begin{array}{l}\text { For fresh consumption, precocious, productive, large } \\
\text { fruit, very firm, sweet and individual peduncles. }\end{array}$ \\
\hline IAC 1.13 & ('IAC Campinas' × 'Dover')/Instituto Agronômico (IAC) & $\begin{array}{l}\text { For fresh consumption, precocious, productive, great } \\
\text { fruit, firm and in bunch. }\end{array}$ \\
\hline IAC 4 & {$[$ (New Jersey $7335-5 \times$ 'Sequoia' $) \times$ 'Fern']/IAC } & $\begin{array}{l}\text { For fresh consumption, precocious, medium to large, } \\
\text { fruit regularly firm, with aroma and in bunch. }\end{array}$ \\
\hline IAC 12 & $($ New Jersey $7335-5 \times$ 'Sweet Charlie')/IAC & $\begin{array}{l}\text { For fresh consumption, precocious, medium to large } \\
\text { fruit, firm, with aroma and in bunch. }\end{array}$ \\
\hline IAC T-0104 & $\begin{array}{l}\text { Pedigree and unknown origin; introduced by } \\
\text { the IAC's strawberry improvement program. }\end{array}$ & Small fruits, regularly firm and in bunch. \\
\hline
\end{tabular}

\subsection{Plant Injury}

This evaluation was conducted in a screenhouse under natural environmental conditions $\left(22-38{ }^{\circ} \mathrm{C} ; 55-75 \% \mathrm{RH}\right.$ and about $13 \mathrm{~h}$ of daily photoperiod), in a randomized block design, with seven treatments (cultivar 'Oso Grande' was not included in the statistical analysis because only three plants were available) and six replicates. Each experimental unit consisted of a plant. Plants of each block were close together, but not touching each other, while blocks were $50 \mathrm{~cm}$ from each other. When plants had 4-7 leaves, i.e. about five months from transplanting, 
ten adult two-spotted spider mites were transferred to the central leaflet of four fully developed leaves of each plant.

After 15 and 30 days, injury caused by the mite was evaluated, assigning a grade to each plant based on the scale of Lourenção et al. (2000), as follows: 1) No symptom of mite attack; 2) Beginning of leaf discoloration, without visible mite web joining leaves; 3 ) About $50 \%$ of the leaves discolored, with visible mite web joining them; 4) Beginning of leaf drying, plants almost completely covered by mite web; 5) Intensive leaf drying, mite web covering the entire plant; 6) Plant death. Evaluations were done independently by four persons at each evaluation time. In the second evaluation, mite density was also estimated by counting the number of mites in $1.0 \mathrm{~cm}^{2}$ in the central area of both faces of three leaflets taken randomly from each plant.

\subsection{Life Table Parameters}

One fertilized female taken randomly from the colony was transferred to each of 20 discs (22 $\mathrm{mm}$ diameter) of mature leaves of each genotype placed onto a piece of foam mat inside a Petri dish $(15 \mathrm{~cm}$ in diameter). The mat was maintained humid by periodic addition of distilled water. Twelve hours later, the females and part of the eggs were removed, leaving only one egg per disc. Subsequent observations were done every $12 \mathrm{~h}$, recording the duration and viability of each immature stage, longevity and fecundity. The mites were maintained in an environmental chamber at $25 \pm 1{ }^{\circ} \mathrm{C}, 70 \pm 5 \% \mathrm{RH}$ and $16 \mathrm{~h}$ of daily photoperiod. Mites were transferred to new discs of the same respective genotype every 3-4 days.

\subsection{Host Preference in Free-Choice Test}

The experiment consisted of a completely randomized design with eight treatments and ten replicates. Each experimental unit consisted of a Petri dish $(15 \mathrm{~cm}$ diameter $)$ containing the distal two thirds of a mature leaflet of each genotype.

The leaflets were distributed at random and equidistantly in a circle along the edge of each dish. The sectioned edge of each leaflet was covered with a layer of cotton wool kept moist to maintain leaflet turgor and to prevent mites from escaping. The distal tip of the leaflets was overlaid with a 8.5 -cm-diameter circle of synthetic resin (Paviflex $\left.{ }^{\circledR}\right)$ to keep the leaflets flat onto the bottom of the plate. Fifty two-spotted spider mite females were randomly taken from bean plants and released in the center of each circle of synthetic resin. The units were kept in an environmental chamber at $25 \pm 1{ }^{\circ} \mathrm{C}, 70 \pm 5 \% \mathrm{RH}$ and $16 \mathrm{~h}$ of daily photoperiod. After $1,6,12$ and $24 \mathrm{~h}$, the number of mites on each leaflet was counted. The number of eggs on each leaflet was also counted in the last evaluation.

\subsection{Trichome Density}

Ten fully expanded leaflets were randomly detached from plants of each genotype, delimiting an area of $16 \mathrm{~mm}^{2}$ near the central region of the ventral surface of each leaflet (including the central vein). Glandular and non-glandular trichomes were counted under a stereomicroscope (Leica MZ 125, 100X). The glandular trichomes have thick walls and are long, appearing mainly in the abaxial face, along the veins, while non-glandular trichomes are pedunculate and capitate, appearing on both leaf surfaces (Appezzato \& Miranda, 1991).

\subsection{Statistical Analysis}

Plant injury data were compared by the Friedman test $(p<0.05)$ in the statistical program R Development Core Team (2013). Life table parameters [net reproductive rate (Ro), intrinsic rates of population increase (rm), finite rate of increase $(\lambda)$ and the mean generation time $(T)$ ] were calculated by using TWOSEX-MSChart software (Chi, 1988, 2008). Proportional data (survivorship and sex ratio) were analyzed with a generalized linear model with binomial distribution, using $\mathrm{R}$ software (R Development Core Team, 2013). Host preference data were compared with Kruskal-Wallis test $(p<0.05)$, while trichome densities were compared with Tukey's test $(p<$ $0.05)$.

\section{Results}

\subsection{Plant Injury}

Significant differences were observed between genotypes. Fifteen days after the infestation, 'IAC Princesa Isabel', IAC T-0104, IAC 12 and IAC 4 had the lowest injury levels $(p<0.001)$ (Table 2). Thirty days later, the first three of these genotypes still showed the lowest injury levels, but in this same evaluation, only 'Albion' differed from other genotypes by the significantly higher mite density $(p<0.001)$ (Table 2); although not included in the statistical analysis, density on 'Oso Grande' was similar to that on 'Albion'. 
Table 2. Injury levels to strawberry genotypes by Tetranychus urticae attack after 15 and 30 days of infestation $( \pm \mathrm{SE})$ and average number of mites per $\mathrm{cm}^{2}( \pm \mathrm{SE})$. Plants maintained in a screenhouse $\left(22-38^{\circ} \mathrm{C}, 55-75 \% \mathrm{RH}\right.$ and about $13 \mathrm{~h}$ of daily photoperiod)

\begin{tabular}{llll}
\hline \multirow{2}{*}{ Genotype } & \multicolumn{2}{c}{ Symptom $^{\mathbf{a}}$} & $\begin{array}{l}\text { Average number of mites } \\
\mathbf{( c m}^{\mathbf{2}} \mathbf{n}\end{array}$ \\
\cline { 2 - 4 } & $\mathbf{1 5}$ days & $\mathbf{3 0 ~ d a y s}$ & $3.1 \pm 0.6 \mathrm{~b}$ \\
\hline 'IAC Princesa Isabel' & $1.2 \pm 0.1 \mathrm{bc}$ & $1.5 \pm 0.1 \mathrm{c}$ & $4.2 \pm 0.8 \mathrm{~b}$ \\
IAC T-0104 & $1.0 \pm 0.0 \mathrm{c}$ & $2.0 \pm 0.1 \mathrm{bc}$ & $4.8 \pm 1.0 \mathrm{~b}$ \\
IAC 12 & $1.0 \pm 0.0 \mathrm{c}$ & $2.0 \pm 0.2 \mathrm{bc}$ & $5.1 \pm 0,6 \mathrm{~b}$ \\
IAC 1.13 & $1.5 \pm 0.1 \mathrm{~b}$ & $2.3 \pm 0.1 \mathrm{ab}$ & $7.0 \pm 1.7 \mathrm{~b}$ \\
IAC 4 & $1.0 \pm 0.0 \mathrm{c}$ & $2.3 \pm 0.2 \mathrm{ab}$ & $17.5 \pm 2.1 \mathrm{a}$ \\
'Albion' & $1.5 \pm 0.1 \mathrm{~b}$ & $3.2 \pm 0.1 \mathrm{a}$ & $8.1 \pm 1.4 \mathrm{~b}$ \\
'IAC Guarani' & $2.5 \pm 0.1 \mathrm{a}$ & $3.2 \pm 0.1 \mathrm{a}$ & $22.2 \pm 3.7$ \\
'Oso Grande'b & $2.2 \pm 0.2$ & $3.2 \pm 0.1$ & \\
\hline
\end{tabular}

Note. Means followed by the same letter in the column differ statistically (Friedman test; $p<0.05$ ). ${ }^{\text {a Scale }}$ according to Lourenção et al. (2000); ${ }^{\mathrm{b}}$ Not included in the statistical analysis.

The relation between injury level and mite density (30 days after plant infestation) suggested similar responses of genotypes in respect to the effect of two-spotted spider mite $\left(p=0.0146 ; \mathrm{R}^{2}=0.657\right.$; Figure 1$)$; in other words, injury level was proportional to mite density when genotypes were considered together. Most divergent genotypes were 'IAC Guarani' and 'IAC Princesa Isabel', the first showing more and the second less damage than expected by the tendency line.

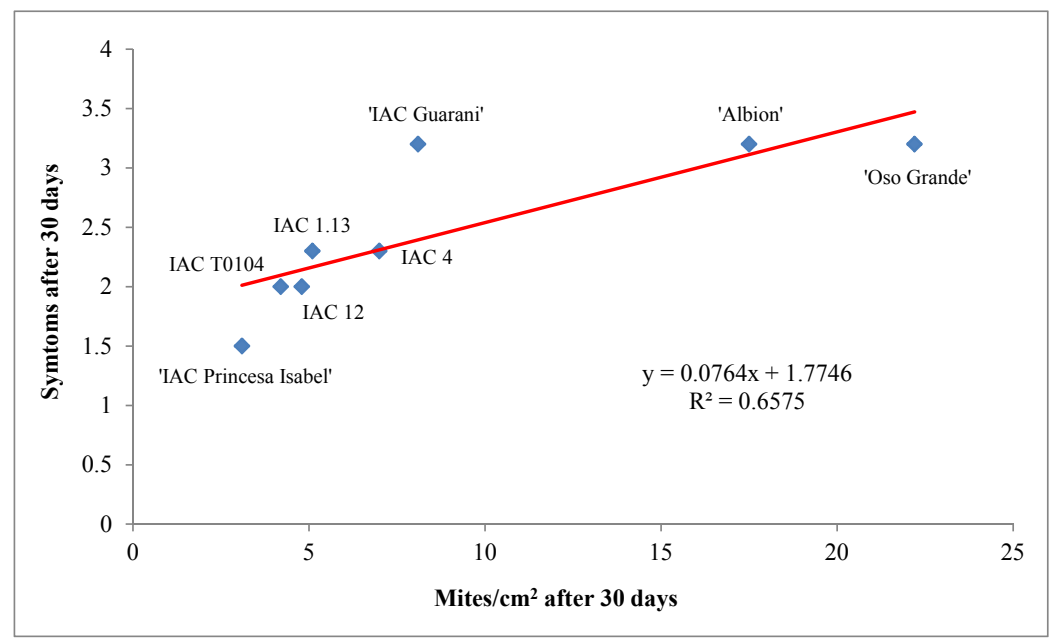

Figure 1. Mite densities and respective injury levels for different strawberry genotypes 30 days after the release of 40 females on each strawberry plant ( $n=240$ leaflet per genotype, except 'Oso Grande', for which $n=120$ )

\subsection{Life Table Parameters}

Survivorship of immatures was always high, the lowest rates being observed on 'IAC Princesa Isabel' (75\%), IAC $1.13(90 \%)$ and IAC $4(95 \%)$; survivorship on other genotypes was $100 \%\left(\mathrm{~F}_{79,18}=3.43 ; \mathrm{p}=0.036\right)($ Table 3). Immature developmental period (egg-adult) was longer on 'IAC Princesa Isabel' and IAC 1.13 and intermediate on IAC 4, IAC T-0104 and IAC 12, although in none of these the different immature stages were consistently longer on these than on the remaining genotypes. Conversely, the first two genotypes had the lowest fecundity rates, whereas the latter three, together with 'IAC Guarani', had intermediate rates (Table 4). Similar pattern of response was observed for daily oviposition rates, except that 'IAC Guarani' had one of the highest rates, together with 'Albion' and 'Oso Grande'. 
Table 3. Developmental time of different stages (in days) and survivorship of Tetranychus urticae (Mean $\pm \mathrm{SE}$ ) on eight strawberry genotypes $\left(25 \pm 1{ }^{\circ} \mathrm{C}, 70 \pm 5 \%\right.$ RH and $16 \mathrm{~h}$ of daily photoperiod)

\begin{tabular}{lllllll}
\hline Genotypes/Stage & Egg & Larva & Protonymph & Deutonymph & $\begin{array}{l}\text { Immature phase } \\
\text { (egg-adult) }\end{array}$ & Survivorship $^{\mathrm{b}}$ \\
\hline 'IAC Princesa Isabel' & $3.8 \pm 0.08 \mathrm{~b}$ & $3.6 \pm 0.44 \mathrm{a}$ & $2.1 \pm 0.24 \mathrm{a}$ & $1.6 \pm 0.15 \mathrm{abc}$ & $11.2 \pm 0.30 \mathrm{a}$ & $0.75 \mathrm{~b}$ \\
IAC T-0104 & $3.8 \pm 0.07 \mathrm{ab}$ & $1.8 \pm 0.14 \mathrm{bc}$ & $1.4 \pm 0.13 \mathrm{c}$ & $1.8 \pm 0.08 \mathrm{a}$ & $8.9 \pm 0.04 \mathrm{~cd}$ & $1.00 \mathrm{a}$ \\
IAC 12 & $3.7 \pm 0.09 \mathrm{~b}$ & $1.9 \pm 0.15 \mathrm{~b}$ & $1.5 \pm 0.11 \mathrm{bc}$ & $1.8 \pm 0.08 \mathrm{a}$ & $9.1 \pm 0.04 \mathrm{~cd}$ & $1.00 \mathrm{a}$ \\
IAC 1.13 & $3.9 \pm 0.01 \mathrm{a}$ & $2.1 \pm 0.23 \mathrm{~b}$ & $1.9 \pm 0.15 \mathrm{a}$ & $2.1 \pm 0.22 \mathrm{a}$ & $10.1 \pm 0.35 \mathrm{~b}$ & $0.90 \mathrm{a}$ \\
IAC 4 & $3.9 \pm 0.01 \mathrm{a}$ & $2.0 \pm 0.15 \mathrm{~b}$ & $2.1 \pm 0.18 \mathrm{a}$ & $1.2 \pm 0.13 \mathrm{~cd}$ & $9.2 \pm 0.20 \mathrm{c}$ & $0.95 \mathrm{a}$ \\
'Albion' & $4.0 \pm 0.00 \mathrm{a}$ & $1.5 \pm 0.11 \mathrm{c}$ & $1.8 \pm 0.13 \mathrm{ab}$ & $1.4 \pm 0.11 \mathrm{bd}$ & $8.7 \pm 0.10 \mathrm{e}$ & $1.00 \mathrm{a}$ \\
'IAC Guarani' & $3.6 \pm 0.14 \mathrm{~b}$ & $1.9 \pm 0.12 \mathrm{~b}$ & $1.2 \pm 0.09 \mathrm{c}$ & $1.6 \pm 0.11 \mathrm{ab}$ & $8.3 \pm 0.19 \mathrm{e}$ & $1.00 \mathrm{a}$ \\
'Oso Grande' & $3.8 \pm 0.08 \mathrm{~b}$ & $1.9 \pm 0.11 \mathrm{bc}$ & $1.2 \pm 0.09 \mathrm{c}$ & $1.7 \pm 0.15 \mathrm{ab}$ & $8.7 \pm 0.15 \mathrm{de}$ & $1.00 \mathrm{a}$ \\
\hline
\end{tabular}

Note. ${ }^{\text {a }}$ Standard errors calculated using the bootstrap procedure with 20.000 bootstraps. In each column, different letters refer to statistical differences between treatments using the paired bootstrap test at 5\% significance level.

${ }^{\mathrm{b}}$ Generalized linear model with binomial distribution.

Table 4. Oviposition period, longevity and reproductive parameters of Tetranychus urticae (Mean \pm SE) on eight strawberry genotypes $\left(25 \pm 1^{\circ} \mathrm{C}, 70 \pm 5 \% \mathrm{RH}\right.$ and $16 \mathrm{~h}$ of daily photoperiod $)$

\begin{tabular}{llllll}
\hline Genotypes/Parameters $^{\mathrm{a}}$ & $\begin{array}{l}\text { Oviposition period } \\
\text { (days) }\end{array}$ & $\begin{array}{l}\text { Longevity female } \\
\text { (days) }\end{array}$ & Sex ratio $^{\mathrm{b}}$ & Daily oviposition $^{\mathbf{c}}$ & Fecundity \\
\hline 'IAC Princesa Isabel' & $13.5 \pm 1.41 \mathrm{~b}$ & $19.2 \pm 1.94 \mathrm{bc}$ & $0.80 \mathrm{a}$ & $3.7 \pm 0.18 \mathrm{c}$ & $50 \pm 5.87 \mathrm{~d}$ \\
IAC T-0104 & $19.1 \pm 2.20 \mathrm{a}$ & $23.1 \pm 2.23 \mathrm{a}$ & $0.90 \mathrm{a}$ & $5.1 \pm 0.17 \mathrm{~b}$ & $97.7 \pm 11.07 \mathrm{bc}$ \\
IAC 12 & $18.7 \pm 1.60 \mathrm{a}$ & $24.2 \pm 1.68 \mathrm{a}$ & $0.90 \mathrm{a}$ & $5.1 \pm 0.16 \mathrm{~b}$ & $93.6 \pm 8.40 \mathrm{bc}$ \\
IAC 1.13 & $11.9 \pm 1.92 \mathrm{~b}$ & $13.7 \pm 2.08 \mathrm{c}$ & $0.85 \mathrm{a}$ & $3.7 \pm 0.20 \mathrm{c}$ & $43.8 \pm 7.96 \mathrm{~d}$ \\
IAC 4 & $18.4 \pm 1.70 \mathrm{a}$ & $23.0 \pm 1.99 \mathrm{a}$ & $0.85 \mathrm{a}$ & $5.1 \pm 0.19 \mathrm{~b}$ & $93.7 \pm 8.84 \mathrm{bc}$ \\
'Albion' & $18.7 \pm 1.40 \mathrm{a}$ & $22.8 \pm 1.78 \mathrm{a}$ & $0.90 \mathrm{a}$ & $5.8 \pm 0.18 \mathrm{ab}$ & $109 \pm 7.72 \mathrm{ab}$ \\
'IAC Guarani' & $12.4 \pm 1.93 \mathrm{~b}$ & $15.4 \pm 1.98 \mathrm{bc}$ & $0.75 \mathrm{a}$ & $6.2 \pm 0.24 \mathrm{ab}$ & $76.1 \pm 10.15 \mathrm{c}$ \\
'Oso Grande' & $20.7 \pm 2.90 \mathrm{a}$ & $22.7 \pm 3.15 \mathrm{ab}$ & $0.85 \mathrm{a}$ & $6.9 \pm 0.27 \mathrm{a}$ & $142 \pm 17.93 \mathrm{a}$ \\
\hline
\end{tabular}

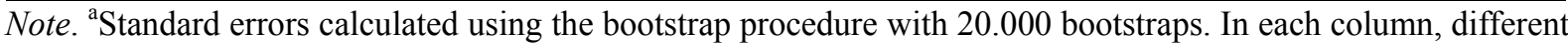
letters refer to statistical differences between treatments using the paired bootstrap test at 5\% significance level.

${ }^{\mathrm{b}}$ Generalized linear model with binomial distribution. ${ }^{\mathrm{c}}$ Averages compared by Tukey's test $(p<0.05)$.

Significantly lower values of the intrinsic rate of increase $\left(\mathrm{r}_{\mathrm{m}}\right)$, finite rate of increase $(\lambda)$ and net reproductive rate (Ro) were obtained on 'IAC Princesa Isabel' and IAC 1.13, while intermediate values were obtained on IAC 4, IAC T-0104, IAC 12 and 'IAC Guarani' (Table 5). Significantly higher values of mean generation time (T) were observed on 'IAC Princesa Isabel', IAC 4 and IAC T-0104, while the lowest T value was observed on 'IAC Guarani'.

Table 5. Life table parameters, intrinsic rate of increase $\left(r_{m}\right)$, finite rate of increase $(\lambda)$, net reproductive rate $\left(R_{0}\right)$ and mean generation time (T) (Mean \pm SE) of Tetranychus urticae on eight strawberry genotypes $\left(25 \pm 1{ }^{\circ} \mathrm{C}, 70 \pm 5 \%\right.$ $\mathrm{RH}$ and $16 \mathrm{~h}$ of daily photoperiod)

\begin{tabular}{lllll}
\hline Parameters $^{\mathbf{a}}$ & $\mathbf{r}_{\mathbf{m}}$ & $\boldsymbol{\lambda}$ & $\mathbf{R}_{\mathbf{0}}$ & T (days) \\
\hline 'IAC Princesa Isabel' & $0.190 \pm 0.01 \mathrm{~d}$ & $1.21 \pm 0.02 \mathrm{~d}$ & $30.00 \pm 6.49 \mathrm{e}$ & $17.8 \pm 0.53 \mathrm{a}$ \\
IAC T-0104 & $0.261 \pm 0.01 \mathrm{bc}$ & $1.30 \pm 0.01 \mathrm{bc}$ & $87.98 \pm 11.95 \mathrm{abc}$ & $16.9 \pm 0.35 \mathrm{ab}$ \\
IAC 12 & $0.262 \pm 0.01 \mathrm{bc}$ & $1.30 \pm 0.01 \mathrm{bc}$ & $84.24 \pm 9.80 \mathrm{abc}$ & $16.6 \pm 0.28 \mathrm{bc}$ \\
IAC 1.13 & $0.214 \pm 0.01 \mathrm{~d}$ & $1.24 \pm 0.01 \mathrm{~d}$ & $32.87 \pm 7.27 \mathrm{de}$ & $16.3 \pm 0.51 \mathrm{bcd}$ \\
IAC 4 & $0.250 \pm 0.01 \mathrm{c}$ & $1.28 \pm 0.01 \mathrm{c}$ & $74.97 \pm 10.92 \mathrm{bc}$ & $17.3 \pm 0.35 \mathrm{ab}$ \\
'Albion' & $0.291 \pm 0.01 \mathrm{a}$ & $1.34 \pm 0.01 \mathrm{a}$ & $98.10 \pm 10.08 \mathrm{ab}$ & $15.3 \pm 0.28 \mathrm{~d}$ \\
'IAC Guarani' & $0.280 \pm 0.01 \mathrm{ab}$ & $1.33 \pm 0.02 \mathrm{ab}$ & $57.08 \pm 10.56 \mathrm{~cd}$ & $14.0 \pm 0.43 \mathrm{e}$ \\
'Oso Grande' & $0.301 \pm 0.01 \mathrm{a}$ & $1.35 \pm 0.01 \mathrm{a}$ & $120.7 \pm 18.94 \mathrm{a}$ & $15.8 \pm 0.34 \mathrm{~cd}$ \\
\hline
\end{tabular}

Note. ${ }^{\text {a }}$ Standard errors calculated using the bootstrap procedure with 20.000 bootstraps. In each column, different letters refer to statistical differences between treatments using paired bootstrap test $(p<0.05)$. 


\subsection{Host Preference in Free-Choice Test}

For all genotypes, there was an increase in the average number or mites per leaflet from the first $(1 \mathrm{~h})$ to the second $(6 \mathrm{~h})$ evaluations, numbers remaining about stable afterwards. This suggested that they needed more than $1 \mathrm{~h}$ to select the genotype. Significant differences between genotypes were detected in all observations, the largest mite numbers being always found on 'IAC Guarani' (Table 6). Accordingly, the highest number of mite eggs at the end of the study was observed on the same genotype. The lowest number was observed on IAC T-0104, one of the genotypes with lowest numbers of mites per leaflet in the first and second evaluations.

Table 6. Average numbers of Tetranychus urticae females and of their eggs per leaflet of eight strawberry genotypes $( \pm \mathrm{SE})$ in a free choice laboratory test $\left(25 \pm 1^{\circ} \mathrm{C} ; 70 \pm 5 \% \mathrm{RH}\right.$ and $16 \mathrm{~h}$ of daily photoperiod)

\begin{tabular}{llllll}
\hline \multirow{2}{*}{ Genotype } & \multicolumn{5}{c}{$\begin{array}{c}\text { Females per evaluation } \\
\text { (h from beginning of the test) }\end{array}$} \\
\cline { 2 - 5 } & $\mathbf{1}$ & $\mathbf{6}$ & $\mathbf{1 2}$ & $\mathbf{2 4}$ & $\begin{array}{c}\text { Eggs } \\
\text { (24h from beginning) }\end{array}$ \\
\hline 'IAC Princesa Isabel' & $6.1 \pm 1.2 \mathrm{ab}$ & $7.3 \pm 1.2 \mathrm{ab}$ & $6.6 \pm 1.1 \mathrm{~b}$ & $6.9 \pm 0.9 \mathrm{ab}$ & $50.1 \pm 7.54 \mathrm{ab}$ \\
IAC T-0104 & $2.8 \pm 0.8 \mathrm{c}$ & $4.5 \pm 0.8 \mathrm{c}$ & $4.3 \pm 0.8 \mathrm{~b}$ & $4.8 \pm 0.8 \mathrm{~b}$ & $25.8 \pm 4.21 \mathrm{c}$ \\
IAC 12 & $4.4 \pm 1.4 \mathrm{abc}$ & $5.6 \pm 1.4 \mathrm{bc}$ & $5.7 \pm 1.5 \mathrm{~b}$ & $5.7 \pm 1.2 \mathrm{~b}$ & $40.7 \pm 7.79 \mathrm{bc}$ \\
IAC 1.13 & $4.6 \pm 1.2 \mathrm{abc}$ & $6.5 \pm 1.2 \mathrm{bc}$ & $6.7 \pm 1.2 \mathrm{~b}$ & $6.3 \pm 1.2 \mathrm{~b}$ & $41.1 \pm 5.33 \mathrm{abc}$ \\
IAC 4 & $3.9 \pm 0.6 \mathrm{abc}$ & $5.1 \pm 0.6 \mathrm{bc}$ & $5.2 \pm 0.6 \mathrm{~b}$ & $4.9 \pm 0.6 \mathrm{~b}$ & $34.5 \pm 3.83 \mathrm{abc}$ \\
'Albion' & $3.4 \pm 1.0 \mathrm{bc}$ & $6.0 \pm 1.0 \mathrm{bc}$ & $6.1 \pm 1.1 \mathrm{~b}$ & $6.2 \pm 1.0 \mathrm{~b}$ & $43.3 \pm 6.94 \mathrm{abc}$ \\
'IAC 'Guarani' & $6.4 \pm 1.2 \mathrm{a}$ & $9.4 \pm 1.2 \mathrm{a}$ & $10.0 \pm 1.2 \mathrm{a}$ & $9.6 \pm 1.2 \mathrm{a}$ & $64.3 \pm 8.21 \mathrm{a}$ \\
'Oso Grande' & $2.8 \pm 0.9 \mathrm{c}$ & $5.1 \pm 0.9 \mathrm{bc}$ & $5.4 \pm 0.8 \mathrm{~b}$ & $5.5 \pm 0.9 \mathrm{~b}$ & $43.7 \pm 7.90 \mathrm{bc}$ \\
\hline
\end{tabular}

Note. In each column, different letters refer to statistical differences between treatments by the Kruskal-Wallis test $(p<0.05)$.

Evaluation of the relationship between the number of females on each genotype (average of all counts in each of the 20 replicates; Figure 2) and the corresponding number of eggs laid (after $24 \mathrm{~h}$ ) showed IAC T-0104 as an outlier (determined by box plot graph). The number of eggs laid on this genotype was much lower than what would be expected in relation to the pattern of other genotypes, as suggested by an examination of the tendency line of the regression between those factors, which were significantly and directly correlated $\left(p=0.0011, \mathrm{R}^{2}=\right.$ 0.8979). In other words, the larger the average number of mites, the larger the number of eggs laid, independently of the genotype, except for IAC T-0104. Considering the equation of that tendency line, it was concluded that the total oviposition by a female during the experiment (24 hours) was approximately 13.5 eggs across genotypes.

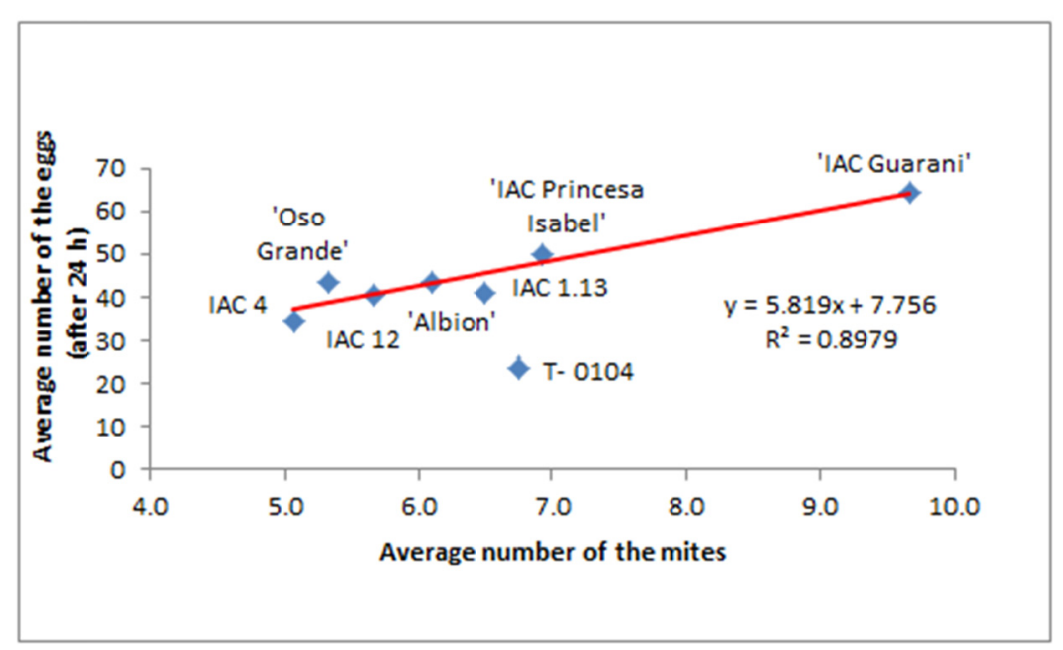

Figura 2. Correlation between average number of Tetranychus urticae eggs counted after $24 \mathrm{~h}$ and average number of mites ( 6,12 and 24 hours) in free-choice test on eight strawberry genotypes 


\subsection{Trichome Density}

A large variation in the average number of trichomes was observed among genotypes $(p=0.039)$ (Table 7). At one extreme, IAC 1.13 differed significantly from other genotypes by having the highest density of total trichomes, whereas the group composed by IAC T-0104, IAC 12, 'Albion' and 'Oso Grande' had the lowest densities. Considering the types of trichomes separately, IAC 1.13 also had significantly higher densities of glandular and non-glandular trichomes than that group of genotypes.

Table 7. Number of glandular, non-glandular and total trichomes/16 $\mathrm{mm}^{2}$ of leaf area (Mean \pm SE) of eight strawberry genotypes

\begin{tabular}{llll}
\hline \multirow{2}{*}{ Genotype } & \multicolumn{3}{c}{ Trichomes } \\
\cline { 2 - 4 } & Glandular & Non-glandular & Total \\
\hline IAC 1.13 & $38.1 \pm 2.81 \mathrm{a}$ & $79.9 \pm 7.12 \mathrm{a}$ & $118.0 \pm 8.66 \mathrm{a}$ \\
'IAC Princesa Isabel' & $24.4 \pm 2.34 \mathrm{bc}$ & $65 \pm 2.27 \mathrm{ab}$ & $89.4 \pm 2.87 \mathrm{~b}$ \\
'IAC Guarani' & $28.4 \pm 1.73 \mathrm{ab}$ & $58.2 \pm 2.54 \mathrm{bc}$ & $86.6 \pm 1.61 \mathrm{~b}$ \\
IAC 4 & $21.6 \pm 3.07 \mathrm{bcd}$ & $52.1 \pm 4.51 \mathrm{bcd}$ & $73.7 \pm 6.33 \mathrm{bc}$ \\
IAC T-0104 & $17 \pm 2.41 \mathrm{~cd}$ & $44.2 \pm 2.41 \mathrm{~cd}$ & $61.2 \pm 1.97 \mathrm{~cd}$ \\
IAC 12 & $11.1 \pm 1.36 \mathrm{~d}$ & $43.1 \pm 2.07 \mathrm{~cd}$ & $54.2 \pm 3.25 \mathrm{~cd}$ \\
'Albion' & $10.6 \pm 0.87 \mathrm{~d}$ & $39.8 \pm 1.77 \mathrm{~cd}$ & $50.4 \pm 2.21 \mathrm{~cd}$ \\
'Oso Grande' & $10.5 \pm 1.29 \mathrm{~d}$ & $35.3 \pm 2.49 \mathrm{~d}$ & $45.8 \pm 3.60 \mathrm{~d}$
\end{tabular}

Note. In each column, means followed by different letters differ significantly by Tukey test $(p<0.05)$.

A significant and positive correlation was observed between the numbers of glandular and non-glandular trichomes on the different genotypes ( $\left.p=0.0001 ; \mathrm{R}^{2}=0.9191\right)$. Thus, relationships between trichomes and other factors were always done taking into account the total number of trichomes. Significant and negative correlations were found between trichome densities of different genotypes and: a) fecundity (life table study; $p=0.0020 ; \mathrm{R}^{2}$ $=0.817$ ); b) longevity (life table study; $p=0.0032 ; \mathrm{R}^{2}=0.7881$ ) (Figure 3 ). No significant correlations were found between trichome densities of different genotypes and: a) number of eggs laid within $24 \mathrm{~h}$ (host preference test; $p=0.5061 ; \mathrm{R}^{2}=0.076$ ); b) oviposition rate per female within $24 \mathrm{~h}$ (host preference test; $p=0.5648 ; \mathrm{R}^{2}=$ 0.058 ); c) daily oviposition rate per female (life table study; $p=0.0517 ; \mathrm{R}^{2}=0.494$ ) and d) number of mites per leaflet within $24 \mathrm{~h}$ (host preference test; $p=0.3209 ; \mathrm{R}^{2}=0.163$ ).

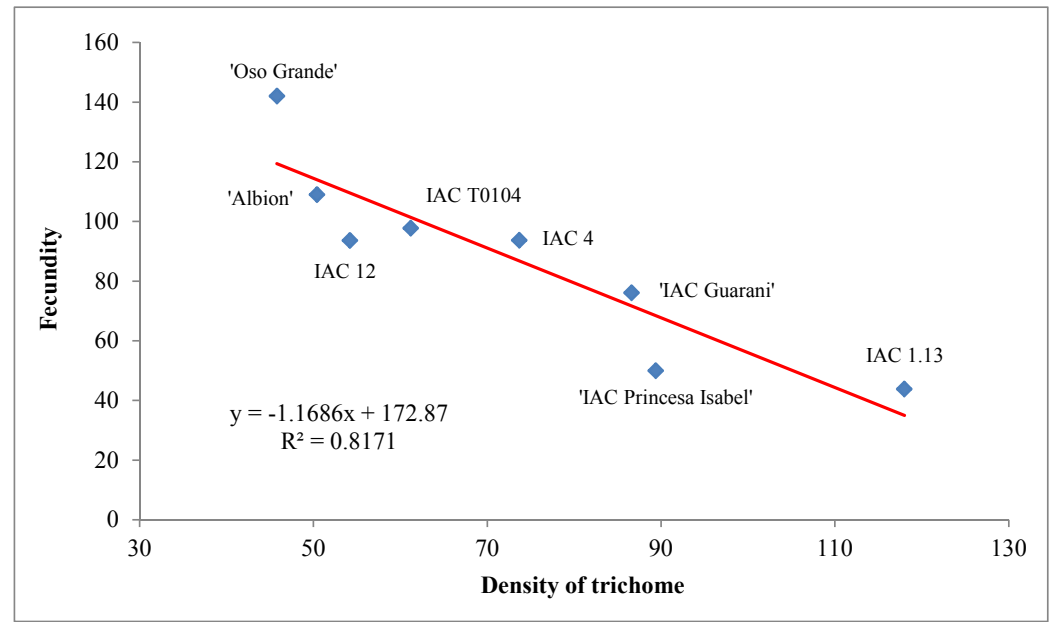

Figura 3. Correlation between trichome density and fecundity of Tetranychus urticae on eight strawberry genotypes 


\section{Discussion}

Among the three less damaged genotypes, 'IAC Princesa Isabel' is an old cultivar, which is not used anymore (Antunes \& Peres, 2013), but which can act as a donor of resistance gene(s). The other two (IAC 12 and IAC T-0104), as well as the genotypes with intermediate damage levels (IAC 4 and IAC 1.13), show considerable potential for future development of cultivars resistant to the two-spotted spider mite. The results suggest that the lower mite damage to these genotypes might be due to the lower reproductive potential of the mite on these, as shown by lower mite density on the plants in the mite injury study, by the lower fecundity determined in the life table study (except IAC 4 and IAC 12) and in the preference test (especially IAC T-0104). In addition, 'IAC Princesa Isabel' appears to be less damaged by each mite than other genotypes, as suggested by the second largest difference between observed and estimated damage level for this genotype.

For some genotypes, differences were observed between the average daily oviposition rates determined in the life table and in the host preference studies. Those differences could be related to fact that in the first study the mites were reared from the egg stage on the genotype under study, whereas in the second they were reared on bean leaves and only the adults were exposed to the respective genotypes.

The lowest values of $r_{m}$ on 'IAC Princesa Isabel' and IAC 1.13 were related to the longer immature developmental time and low fecundity of the mite on these than on other genotypes. Concurrently, 'IAC Princesa Isabel' and IAC 1.13 had the highest densities of both glandular and non-glandular trichomes, and this characteristic could also have an important bearing in the low $r_{m}$ values. The non significant correlations between trichome densities and number of mites per leaflets and number of eggs laid within $24 \mathrm{~h}$ (in the host preference), as well as between trichome densities and daily oviposition rate (in the life table study) suggest that trichomes have no significant effect on the mite in relation to those parameters. However, those results seem to contrast with the observed negative correlation between trichome density and fecundity, determined in the life table study. This contrast might be explained by the higher mite longevity on leaflets with lower trichome densities, shown in this study.

Contradictory results have been shown in the literature concerning the role of trichomes in plant resistance to two-spotted spider mite (Steinite \& Ievinsh, 2003). Negative effect of glandular and non-glandular (tector) trichomes on strawberry leaves on oviposition and survivorship of the two-spotted spider mite was reported by Luczynski, Isman, Raworth, and Chan (1990). However, in an extensive field evaluation of 29 strawberry genotypes, Kishaba, Voth, Howland, Bringhurst, and Toba (1972) observed higher susceptibility to two-spotted spider mite by genotypes with denser pubescence. About 30 years later, Steinite and Ievinsh (2003) concluded that the susceptibility of strawberry cultivars were not related to the density of total trichomes, but rather to the density of glandular trichomes. In relating trichome densities to two-spotted spider mite behavior, Figueiredo et al. (2013) showed that on strawberry varieties with greater densities of glandular trichomes the mite moved less, suggesting that this type of evaluation could allow the determination of resistant strawberry cultivars. Although working with a different host plant (tomato), Maluf et al. (2007) also concluded that genotypes with higher densities of glandular trichomes had higher mite-resistance, as suggested by an evaluation of the distance walked by the mite onto the tomato leaf surface.

Glandular trichomes can produce compounds with toxic or antidigestive properties to immature stages of herbivores (Roda \& Baldwin, 2003), and this may explain the higher mortality rate of immature two-spotted spider mite on 'IAC Princesa Isabel' in this study (25\% did not reach adulthood). Concurrently, this cultivar showed the lowest injury level as well as very low mite densities in the study of plant injury, in agreement with the result obtained by Lourenção et al. (2000).

Amongst the most damaged genotypes, 'Albion' and 'Oso Grande' are among the presently most extensively planted cultivars in southeastern Brazil, while 'IAC Guarani' is no longer cultivated (Antunes \& Reisser Jr., 2007; Antunes \& Peres, 2013). The high levels of damage on these cultivars are related to the high $\mathrm{r}_{\mathrm{m}}$ in comparison with other genotypes, which in turn appears to be related to the shortest immature developmental period and the low densities of glandular and non-glandular trichomes (intermediate densities in 'IAC Guarani') in comparison with other genotypes. In addition, 'IAC Guarani' appears to be more intensively damaged by each mite than the other genotypes, as reflected by the largest difference between observed and expected damage level, according to tendency line relating damage to mite density.

In this study, the plants were artificially infested. As plants were maintained in a screenhouse where air movement was low [certainly less than of $24 \mathrm{~km} / \mathrm{h}$, considered an adequate speed for mite dispersion according to Boykin and Campbell (1984)], the mite ultimately was not given the chance to disperse from the less suitable 
genotypes, having no alternative but to stay on the plants onto which they were inoculated. Thus, it is possible that injury could have been less on the least suitable genotypes if plants were maintained in open fields.

Considering the results of all the experiments, it can be concluded that 'IAC Princesa Isabel', IAC T-0104 and IAC 12 are resistant to the mite, while IAC 4 and IAC 1.13 are moderately resistant. Based on the biological data of the two-spotted spider mite on 'IAC Princesa Isabel' (Tables 3 and 4), this cultivar appears to be a carrier of antibiosis, a type of resistance characterized by the negative effect of the plant in parameters such as development, survival and reproduction of the damaging organism. The present study confirmed the susceptibility of 'IAC Guarani', to two-spotted spider mite, as previous observed by Lourenção et al. (2000). This variety, together with the cultivars 'Oso Grande' and 'Albion' were also shown to be susceptible to the mite. Additionally, 'IAC Princesa Isabel' as well as the IAC's material were shown as promising for use in breeding programs for resistance to two-spotted spider mite, reducing strawberry production costs while restricting the use of acaricides for mite control.

\section{Acknowledgements}

This study was funded by CAPES (Coordenação de Aperfeiçoamento de Pessoal de Nível Superior) and by The Research Council of Norway through the SMARTCROP project (project number 244526) which is a project led by Dr Ingeborg Klingen at NIBIO, Norwegian Institute of Bioeconomy Research.

\section{References}

Afifi, A. A. M., El-Laithy, A. Y. M., Shehata, S. A., \& El-Saiedy, E. S. M. A. (2010). Resistance of strawberry plants against the two-spotted spider mite, Tetranychus urticae (Acari: Tetranychidae). In M. Sabelis, \& J. Bruin (Eds.), Trends in Acarology. Springer, Dordrecht. https://doi.org/10.1007/978-90-481-9837-5_85

Antunes, L. E. C., \& Peres, N. A. (2013). Strawberry production in Brazil and South America. Int J Fruit Sci, 13(1-2), 156-161. https://doi.org/10.1080/15538362.2012.698147

Antunes, L. E. C., \& Reisser Júnior, C. (2007). Fragole, i produttori brasiliani mirano all esportazione in Europa. Frutticoltura, 69(5), 60-65.

Appezzato-da-Glória, B., \& Miranda-Stalder, S. H. G. (1991). Anatomia foliar e do pedúnculo floral de plantas de morangueiro (Fragaria $\times$ ananassa) 'Sequóia' tratadas com fitorreguladores. Anais da Escola Superior de Agricultura Luiz de Queiroz, 48, 127-154. https://doi.org/10.1590/S0071-12761991000100008

Attia, S., Grissa, K. L., Lognay, G., Bitume, E., Hance, T., \& Mailleux, A. C. (2013). A review of the major biological approaches to control the worldwide pest Tetranychus urticae (Acari: Tetranychidae) with special reference to natural pesticides. J Pest Sci, 86(3), 361-386. https://doi.org/10.1007/s10340-013-0503-0

Boykin, L. S., \& Campbell, W. V. (1984). Wind Dispersal of the twospotted spider mite (Acari: Tetranychidae) in North Carolina peanut fields. Environ Entomol, 13(1), 221-227. https://doi.org/10.1093/ee/13.1.221

Cavalcanti, S. C. H., Niculau, E. S., Blank, A. F., Câmara, C. A. G., Araújo, I. N., \& Alves, P. B. (2010). Composition and acaricidal activity of Lippia sidoides essential oil against two-spotted spider mite (Tetranychus urticae Koch). Bioresour Technol, 101(2), 829-832. https://doi.org/10.1016/j.biortech.2009. 08.053

Chi, H. (1988). Life-table analysis incorporating both sexes and variable development rates among individuals. Environ Entomol, 17(1), 26-34. https://doi.org/10.1093/ee/17.1.26

Chi, H. (2008). TWOSEX-MSCHART. A computer program for age stage, two-sex life table analysis. https://doi.org/140.120.197.173/Ecology

Dias, J. P. T., Filho, J. D., Carmo, E. L., Simões, J. C., \& Pádua, J. G. (2012). Population fluctuation of spider mite Tetranychus urticae in different production systems of strawberry. Acta Hort (ISHS), 926, 625-630. https://doi.org/10.17660/ActaHortic.2012.926.90

El-Shafei, G. M. A., \& Gotoh, T. (2010). Performance of eighteen tetranychid mite species (Acari: Tetranychidae) on borage and strawberry. Appl Entomol Zool, 45(8), 579-585. http://doi.org/10.1303/aez.2010.579

Fachinello, J. C., Pasa, M. S., Schmtiz, J. D., \& Betemps, D. L. (2011). Situação e perspectivas da fruticultura de clima temperado no Brasil. Rev. Bras. Fruticultura, 33(1), 109-120. https://dx.doi.org/10.1590/S0100-2945 2011000500014

Figueiredo, A. S. T., Resende, J. T. V., Morales, R. G. F., Gonçalves, A. P. S., \& Da Silva, P. R. (2013). The role of glandular and non-glandular trichomes in the negative interactions between strawberry cultivars and spider mite. Arthropod-Plant Interact, 7(1), 53-58. https://doi.org/10.1007/s11829-012-9218-z 
Fraulo, A. B., Mcsorley, R., \& Liburd, O. E. (2008). Effect of the biological control agent Neoseiulus californicus (Acari: Phytoseiidae) on arthropod community structure in North Florida strawberry fields. Fla Entomol, 91(3), 436-445. https://doi.org/10.1653/0015-4040(2008)91[436:EOTBCA]2.0.CO;2

González-Domínguez, S. G., Santillán-Galicia, M. T., González-Hernández, V., Espinosa, J. S., \& González-Hernández, H. (2015). Variability in damage caused by the mite Tetranychus urticae (Trombidiformes: Tetranychidae) Koch on three varieties of strawberry. J Economic Entomol, 108(3), 1371-1380. https://doi.org/10.1093/jee/tov084

Gugole Ottaviano, M. F., Sánchez, N. E., Roggiero, M. F., \& Greco, N. M. (2013). Performance of Tetranychus urticae and Neoseiulus californicus on strawberry cultivars and assessment of the effect of glandular trichomes. Arthropod Plant Interact, 7(5), 547-554. https:// 10.1007/s11829-013-9268-X

Handley, R., Ekbom, B., \& Agren, J. (2005). Variation in trichome density and resistance against a specialist insect herbivore in natural populations of Arabidopsis thaliana. Ecol Entomol, 30(3), $284-292$. https://doi.org/10.1111/j.0307-6946.2005.00699.x

Kishaba, A. N., Voth, V., Howland, A. F., Bringhurst, R. S., \& Toba, H. H. (1972). Twospotted spider mite resistance in California strawberries. J Econ Entomol, 65(1), 117-119. https://doi.org/10.1093/jee/65.1.117

Klingen, I., \& Westrum, K. (2007). The effect of pesticides used in strawberries on the phytophagous mite Tetranychus urticae (Acari: Tetranychidae) and its fungal natural enemy Neozygites floridana (Zygomycetes: Entomophthorales). Biol Control, 43(2), 222-230. http://doi.org/10.1016/j.biocontrol.2007. 07.013

León, L. L., Guzmán, O. D. L. A., García, B. J. A., Chávez, M. C. G., \& Penã, C. J. J. (2014). Consideraciones para mejorar la competitividad de la región "El Bajío" en la producción nacional de fresa. Rev Mex Cienc Agric, 5(4), 673-686.

Lourenção, A. L., Moraes, G. J., Passos, F. A., Ambrosano, G. M. B., \& Silva, L. V. F. (2000). Resistência de morangueiros a Tetranychus urticae Koch (Acari: Tetranychidae). An Soc Entomol Bras, 29(2), 339-346. https://dx.doi.org/10.1590/S0301-80592000000200016

Luczynski, A., Isman, M. B., Raworth, D. A., \& Chan, C. K. (1990). Chemical and morphological factors of resistance against the twospotted spider mite in beach strawberry. J Econ Entomol, 83(2), 564-569. https://doi.org/10.1093/jee/83.2.564

Maluf, W. R., Inoue, I. F., Ferreira, R. P. D., Gomes, L. A. A., Castro, E. M. de, \& Cardoso, M. G. (2007). Higher glandular trichome density in tomato leaflets and repellence to spider mites. Pesq. Agropec. Bras., 42(9), 1227-1235. https://doi.org/10.1590/S0100-204X2007000900003

MCMurtry, J. A., \& Croft, B. A. (1997). Life-styles of phytoseiid mites and their roles in biological control. Annu Rev Entomol, 42(1), 291-321. https://doi.org/10.1146/annurev.ento.42.1.291

MCMurtry, J. A., Moraes, G. J. D., \& Sourassou, N. F. (2013). Revision of the lifestyles of phytoseiid mites (Acari: Phytoseiidae) and implications for biological control strategies. Syst Appl Acarol, 18(4), 297-320. https://doi.org/10.11158/saa.18.4.1

Monteiro, L. B., Kuhn, T. M. A., Mogor, A. F., \& Silva, E. D. B. (2014). Biology of the two-spotted spider mite on strawberry plants. Neotrop Entomol, 43(2), 183-188. https://doi.org/10.1007/s13744-013-0184-7

Moraes, G. J., \& Flechtmann, C. H. W. (2008). Manual de acarologia: Acarologia básica e ácaros de plantas cultivadas no Brasil. Ribeirão Preto, SP: Editora Holos.

Oku, K., Yano, S., \& Takafuji, A. (2006). Host plant acceptance by the phytophagous mite Tetranychus kanzawai Kishida is affected by the availability of a refuge on the leaf surface. Ecol Res, 21(3), 446-452. https://doi.org/10.1007/s11284-005-0141-y

Oliveira, H., Janssen, A., Pallini, A., Venzon, M., Fadini, M., \& Duarte, V. (2007). A phytoseiid predator from the tropics as potential biological control agent for the spider mite Tetranychus urticae Koch (Acari: Tetranychidae). Biol Control, 42(2), 105-109. https://doi.org/10.1016/j.biocontrol.2007.04.011

Park, Y. L., \& Lee, J. H. (2005). Impact of twospotted spider mites (Acari: Tetranychidae) on growth and productivity of glasshouse cucumbers. J Econ Entomol, 98(2), 457-463. https://doi.org/10.1603/0022-049398.2.457

Petrova, V., Cudare, Z., Steinite, I., \& Laugale, V. (2000). Preliminary studies on resistance of some strawberry cultivars to spider mite Tetranychus urticae. IOBC WPRS Bull, 23(11), 119-122. 
R Development Core Team. (2013). R: A language and environment for statistical computing. R Foundation for Statistical Computing, Vienna. Retrieved from http://www.Rproject.org/

Roda, A., \& Baldwin, I. T. (2003). Molecular technology reveals how the induced direct defenses of plants work. Basic Appl Ecol, 4(1), 15-26. https://doi.org/10.1078/1439-1791-00130

Steinite, I., \& Ievinsh, G. (2002). Wound-induced responses in leaves of strawberry cultivars differing in susceptibility to spider mite. J Plant Physiol, 159(5), 491-497. https://doi.org/10.1078/0176-1617-00683

Steinite, I., \& Ievinsh, G. (2003). Possible role of trichomes in resistance of strawberry cultivars against spider mite. Acta Univ Latviensis Ser Biol, 662, 59-65.

Van Leeuwen, T., Vontas, J., Tsagkarakou, A., Dermauw, W., \& Tirry, L. (2010). Acaricide resistance mechanisms in the two-spotted spider mite Tetranychus urticae and other important Acari: A review. Insect Biochem Mol Biol, 40(8), 563-572. https://doi.org/10.1016/j.ibmb.2010.05.008

Wold, S. J., \& Hutchison, W. D. (2003). Varietal resistance to Tetranychus urticae Koch (Acari: Tetranychidae) in Minnesota strawberries and control with bifenthrin. J Entomol Sci, 38(4), 692-695.

\section{Copyrights}

Copyright for this article is retained by the author(s), with first publication rights granted to the journal.

This is an open-access article distributed under the terms and conditions of the Creative Commons Attribution license (http://creativecommons.org/licenses/by/4.0/). 